\title{
Municipal waste management on the example of the Municipal Waste Management Company in Olsztyn - a case study
}

\author{
Jolanta Fieducik ${ }^{1, *}$ \\ ${ }^{1}$ University of Warmia and Mazury in Olsztyn, Faculty of Technical Sciences, Poland
}

\begin{abstract}
This article presents the technological processes associated with waste management on the example of the Municipal Waste Treatment Plant in Olsztyn. Legal acts regulating waste management and the maintenance of cleanliness at the municipal level are discussed. The Municipal Waste Treatment Plant in Olsztyn processes waste from 37 municipalities in the Region of Warmia and Mazury. Waste transported to the plant is separated into sorted waste and mixed waste which undergoes further processing. An innovative solution in the country of drying waste mixed in bioreactors, where aerobic biodegradation occurs, was applied in Olsztyn. As a result of the temperature in this process, the waste is dried without additional energy from the outside. Processed waste is used in the production of alternative fuel. Around $5-15 \%$ of the collected waste is not fit for processing, and it is landfilled.
\end{abstract}

\section{Waste management regulations}

In Poland, waste management is regulated by the Waste Act of 14 December 2012 with subsequent amendments. The Act defines the means that are required to protect of the environment, human life and health, minimize the negative impact of waste generation and waste management on the environment and human life, minimize the adverse consequences of resource use and improve resource efficiency.

The basic concepts related to waste management are defined by the cited Act.

Waste - every substance or object which the holder discards, intends to discard or is required to discard.

Preparing for reuse - inspection, cleaning or recovery operations by which products or components that have become waste are prepared for reuse without other pre-processing; Biowaste - biodegradable waste from gardens and parks, food and kitchen waste from households, restaurants, catering facilities and retail outlets, and similar types of waste from food processing plants;

Green waste - municipal waste composed of biomass from urban green areas, gardens, parks, cemeteries and market squares, excluding waste from street cleaning;

$\underline{\text { Treatment }}$ - recovery and disposal operations, including preparation prior to recovery or disposal;

*Corresponding author: jolanta.fieducik@uwm.edu.pl 
Separate collection - collection of waste at the source where a waste stream is kept separately by type and nature to facilitate specific treatment;

Waste management - the collection, transport and processing of waste, including control over such operations, actions required after the closure of disposal sites and operations performed by waste dealers and brokers;

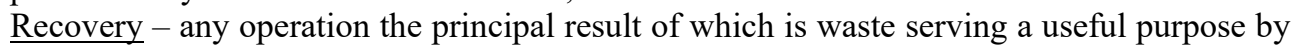
replacing other materials that would otherwise be used to fulfill a particular function, or waste being prepared to fulfill that function in a plant or in the wider economy;

Recycling - any recovery operation by which waste materials are reprocessed into products, materials or substances for the original purpose or other purposes. This includes the reprocessing of organic material (organic recycling), but not energy recovery and the reprocessing into materials that are to be used as fuels or for backfilling operations;

Disposal - any operation which is not recovery, even if the secondary consequence of that operation is the reclamation of substances or energy;

Waste collection - the gathering of waste before transport to a waste treatment facility, including preliminary sorting which does not lead to substantial changes in the nature and composition of waste or waste classification, and temporary storage of waste;

Waste storage - temporary storage of waste, including:

a) preliminary storage of waste pending collection,

b) temporary storage of waste prior to recovery,

c) storage of waste pending treatment [1].

The management of municipal waste is regulated by the Act on the maintenance of cleanliness and order in municipalities which has entered into force on 9 June 2017. Municipal authorities are the holders of waste, and they are legally required to organize the entire waste disposal process [2]. The construction of waste incineration plants has been planned by six Polish regions. This concept had also been analysed in Olsztyn, but the local authorities ultimately opted for a system for the mechanical and biological treatment of municipal waste (MBT). Systems of the type convert mixed municipal waste into alternative fuel. However, the disposal process is not complete because in the light of legal regulations, alternative fuel constitutes waste that has to be disposed. As of 2016, waste with calorific value higher than $6 \mathrm{GJ} / \mathrm{Mg}$ cannot be landfilled. The central part of the Region of Warmia and Mazury, including the city of Olsztyn, generates 50,000 tons of alternative fuel, and the entire region - nearly 10,000 tons each year.

\section{Waste management and treatment in Olsztyn}

The Municipal Waste Treatment Plant in Olsztyn (ZUOK) has been commissioned for use in the last quarter of 2015 [3].

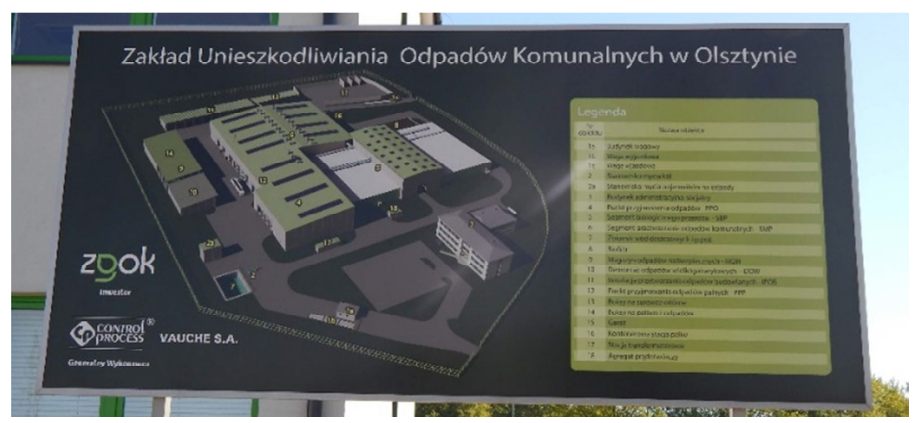

Fig. 1. Site plan of the Municipal Waste Treatment Plant in Olsztyn. 
The construction of the plant has been co-financed by the European Union under the project entitled "Municipal waste management system in Olsztyn, Construction of a Waste Treatment Plant". The project has been developed by the Municipal Waste Management Company which administers waste collection and treatment operations in 37 municipalities in the Region of Warmia and Mazury. The Municipal Waste Treatment Company (ZGOK) is situated in an industrial zone of Olsztyn. It occupies an area of around 5.5 ha in Olsztyn's Track-Wschód district. The process of managing municipal waste in Olsztyn is presented in the diagram in Figure 2.
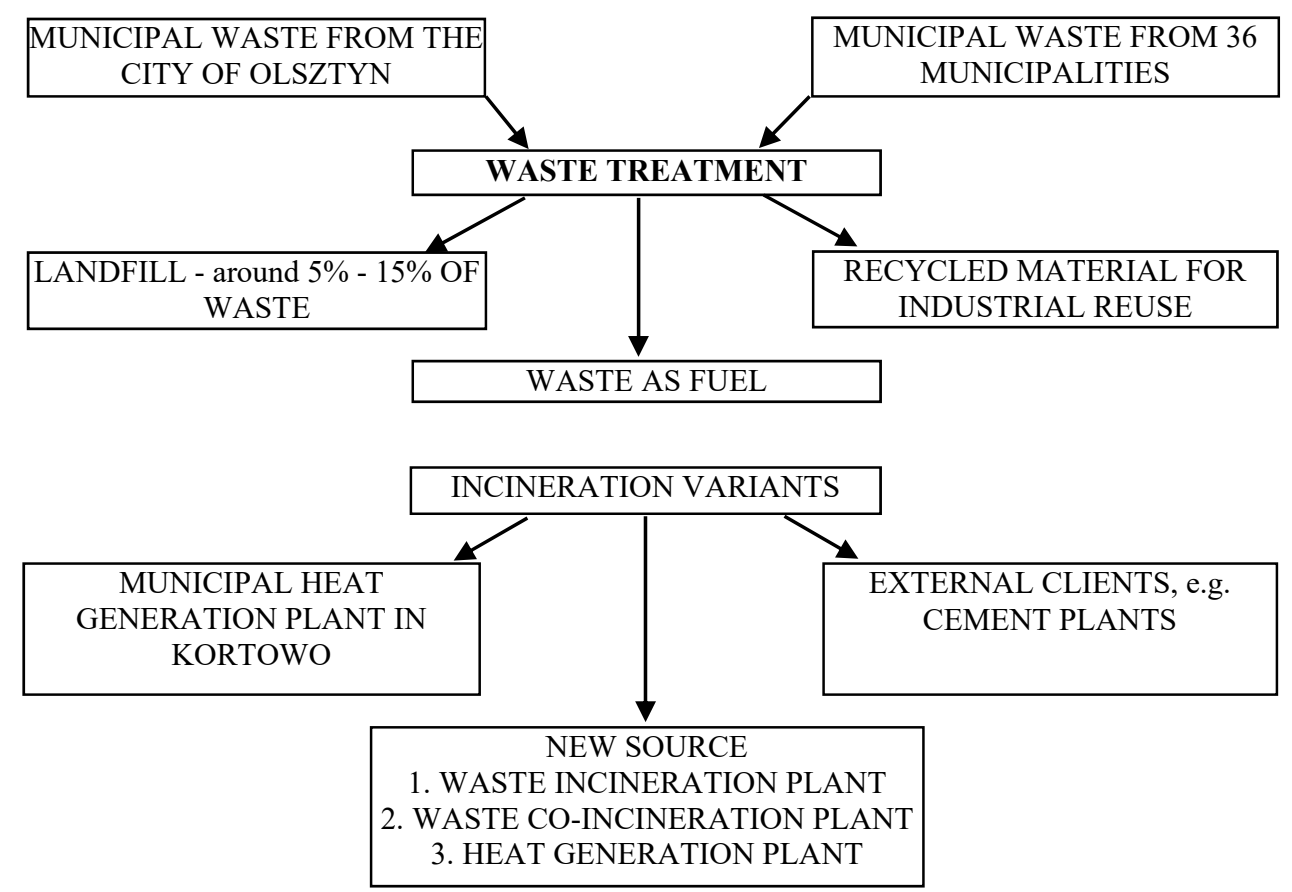

Fig. 2. Municipal waste management process.

According to Central Statistical Office (GUS) data, the Region of Warmia and Mazury had a population of $1,436,400$ and occupied an area of $24,192 \mathrm{~km}^{2}$ in 2016 . The described waste management process involves 37 municipalities in 8 counties of the Region of Warmia and Mazury (Barczewo, Bartoszyce municipality, Bartoszyce town, Biskupiec, Dobre Miasto, Dywity, Dźwierzuty, Gietrzwałd, Górowo Iławeckie municipality, Górowo Iławeckie town, Jedwabno, Jeziorany, Kiwity, Kolno, Korsze, Lidzbark Warmiński municipality, Lidzbark Warmiński town, Lubomino, Mikołajki, Mrągowo municipality, Mrągowo town, Olsztyn, Orneta, Pasym, Piecki, Pisz, Purda, Rozogi, Ruciane Nida, Sępopol, Sorkwity, Stawiguda, Szczytno municipality, Szczytno town, Swiątki, Świętajno, Wielbark) with a combined population of around 500,000. The flow of specific wastes in the region is presented in Figure 3. According to GUS, waste generation per capita in Poland was estimated at $350 \mathrm{~kg}$ in 2016. The Region of Warmia and Mazury operates waste reloading facilities in Medyny, Polska Wieś and Trelkowo. Municipal authorities initiate various educational programs to popularize the importance of waste sorting and to disseminate information about waste sorting methods. Local residents are advised to sort the following types of waste in separate containers: paper, plastic, ash, green waste, glass, mixed waste, bulk waste, construction debris and hazardous waste. 


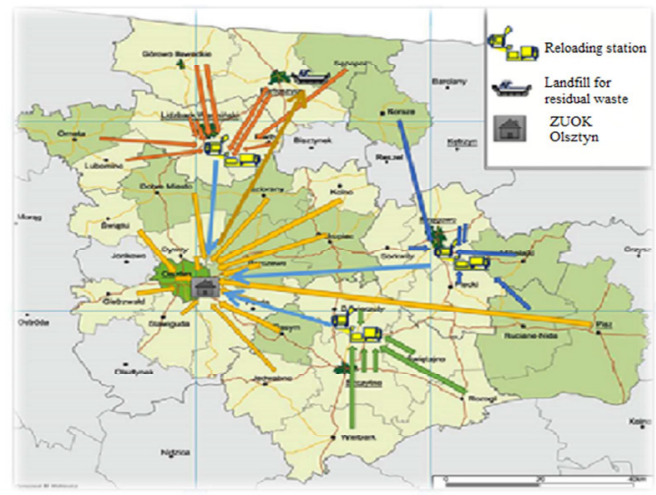

Waste transported from municipalities to:

ZUOK

$\checkmark$ Medyny

Polska Wieś

Trelkowo

Waste transported from the station to ZUOK

Disposal of residual

waste

Fig. 3. Waste stream flows in the Region of Warmia and Mazury.

The collection of selected types of waste and problematic waste directly from households is not economically justified, and these types of waste can be disposed of in selective waste collection points.

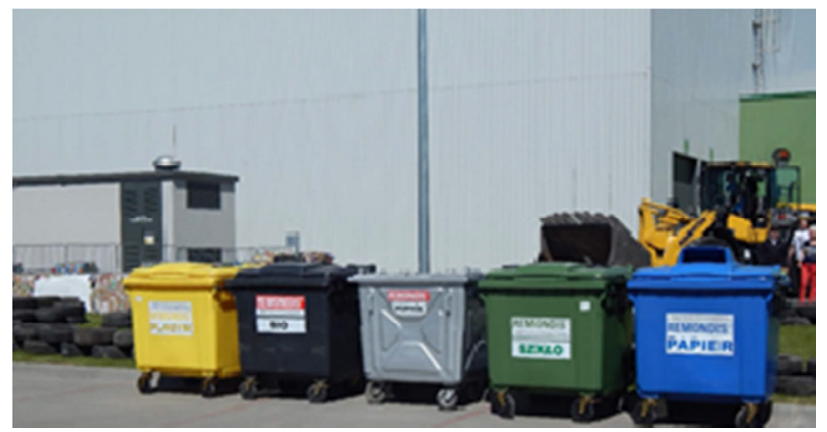

Fig. 4. Selective waste collection containers in the Municipal Waste Treatment Plant.

The following types of problematic municipal waste can be disposed of in selective waste collection points:

- construction and demolition waste,

- bulk waste (furniture, interior furnishings, etc.),

- used household appliances and electronic equipment (washing machines, refrigerators, TV sets, radio sets, computers, calculators, etc.)

- used batteries,

- expired medications, syringes, etc.,

- tires,

- hazardous household waste (residual paint, varnish, solvent, acid, oil, coolant, etc.). This type of waste can be disposed of at no charge in selected collection points [4].

\section{Mixed waste treatment in ZGOK Olsztyn}

The first stage of the project entitled "The municipal waste management system in Olsztyn, Construction of a Waste Treatment Plant" involved the construction of the Municipal Waste Treatment Plant in Olsztyn with a system for the mechanical and biological treatment of waste which processes suitable types of waste into alternative fuel and reduces the amount of inorganic residual waste. 
As part of the above undertaking, auxiliary systems have also been developed to manage all municipal waste streams generated in the central part of the Region of Warmia and Mazury.

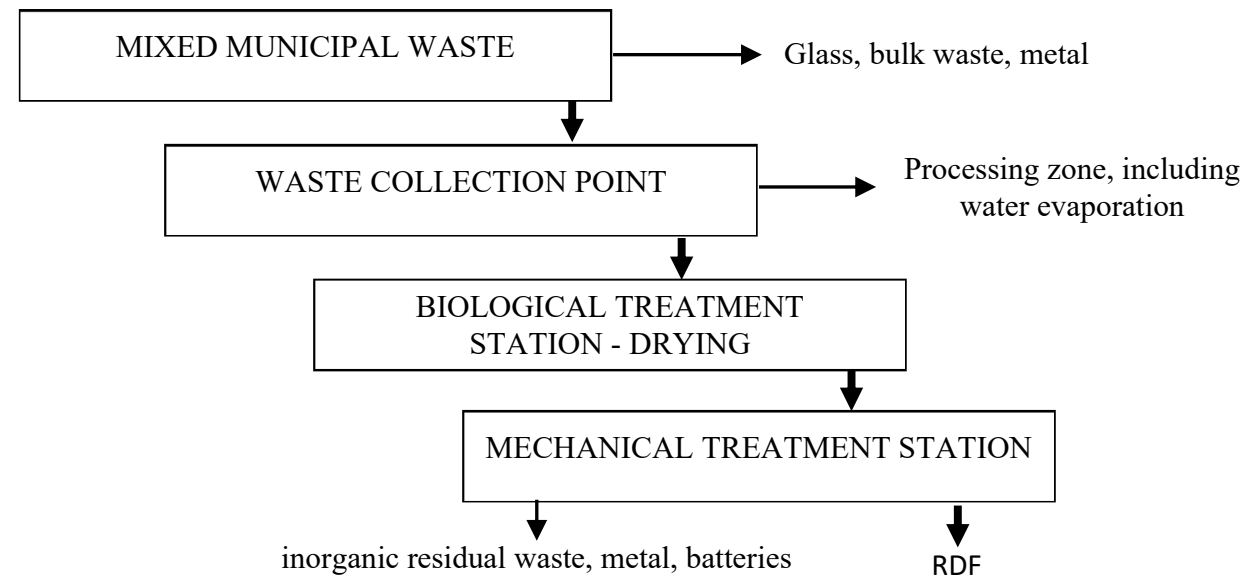

Fig. 5. Diagram of the waste treatment process in ZGOK in Olsztyn.

To ensure the effective operation of the system for the management and treatment of waste generated in the central part of the region, waste has to be sorted at the source to minimize the quantity of mixed waste.

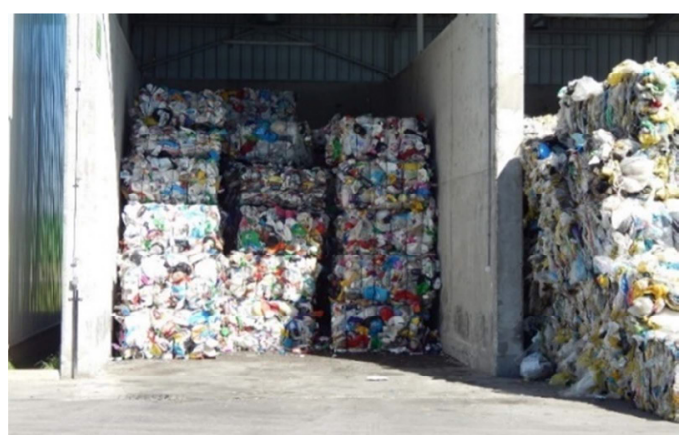

Fig. 6. Sorted waste stored under canopies.

The resulting waste is processed to recover materials and energy. The waste fraction with high calorific value is separated, leaving inorganic residual waste which is landfilled separately from hazardous waste. Each year, ZUOK processes around 130,000 Mg of mixed waste from 37 municipalities. The system for mechanical and biological treatment of waste in ZUOK processes around 100,000 Mg of municipal waste each year. The system is composed of the following facilities:

a) mechanical and biological waste treatment line with nominal processing capacity of $125,000 \mathrm{Mg}$ /year, located in the main hall. The line processes solid waste into alternative fuel and removes recyclable materials from the waste stream. The line is composed of:

- mixed waste collection point (PPO) with an unloading zone and loading equipment.

Waste storage time in the unloading zone and the adverse environmental impact of collected waste (odor, contamination) are kept to a minimum. The unloading zone has water-tight flooring and negative-pressure ventilation with air curtains in entrances to prevent odors from escaping into the ambient. Vehicles transporting waste are unloaded only inside the facility. 


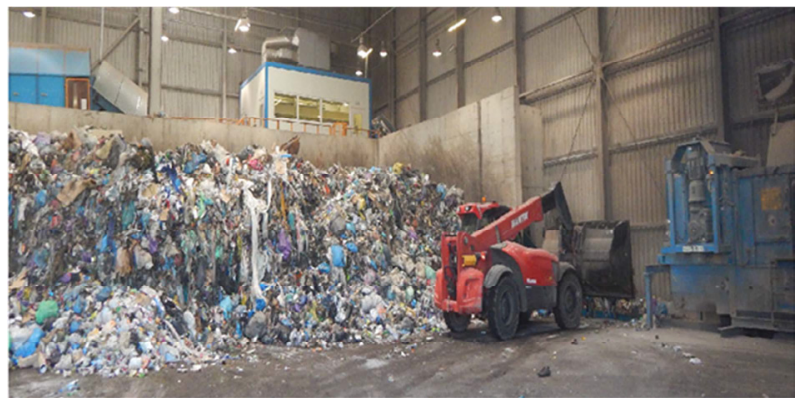

Fig. 7. Waste collection point.

- combustible waste collection point (PPP) - this segment of the mechanical treatment station (SMP) is equipped with a waste shredder, and it processes wastes with high calorific value, such as furniture parts, Christmas trees and wood.

- biological treatment station (SBP) with devices and systems for biological drying (moisture is removed from waste in a series of biochemical reactions, without the involvement of external energy sources, such as electricity generated from the combustion of fossil fuels). Dried waste is a semi-processed product that can be easily split into fractions, purified or shredded for the production of alternative fuel.

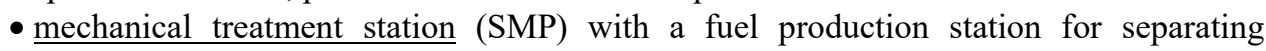
combustible and non-combustible waste and removing recyclable materials (metal, nonmetal) from the waste stream. The produced fuel is processed in the station, and inorganic residual waste (for landfilling) is separated and stored until transport.

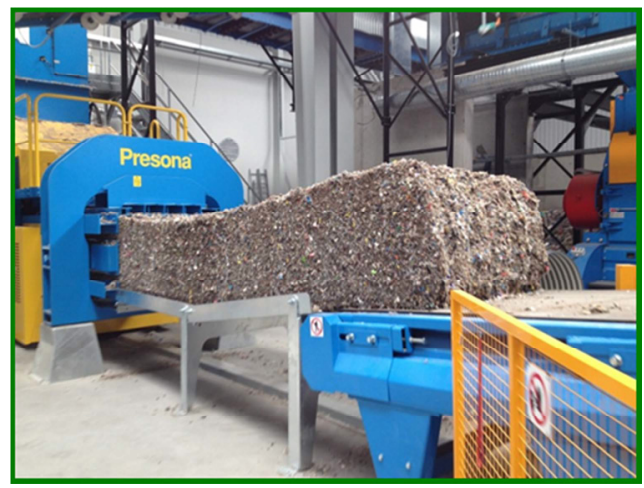

Fig. 8. Fuel processing station.

b) auxiliary systems in the mechanical and biological waste treatment line, including:

- odor control system where waste odors are neutralized with preliminary dust removal,

- waste sorting facilities are equipped with a negative-pressure ventilation system and air exhausts in the ceiling to prevent odors from escaping into the ambient. Exhaust air is transported to the waste drying chamber.

- measurement and control system which can be operated from the main control room and local displays on the equipment;

- main power supply and control unit with local units and cable conduits connecting all system devices.

c) packaging waste sorting line (SOO) with processing capacity of $16,000 \mathrm{Mg} /$ year;

d) auxiliary systems for managing bulk waste, construction debris and hazardous waste; hazardous waste is temporarily stored in a controlled and safe manner, and it is 
transported to specialist disposal sites. Construction debris and bulk waste are collected by providers of specialist recycling services.

\section{Waste treatment line}

Mixed waste transported to the plant is weighed and unloaded. There are plans to build a waste reservoir as a storage and maneuvering area measuring $36.4 \times 21.0 \mathrm{~m}$ with an estimated volume of $2,600 \mathrm{~m}^{3}$. The supplied waste can be stored in the reservoir for up to 3 days. Waste stored in the reservoir will be pre-sorted. Obstructing waste and bulk waste that can damage the waste treatment line or compromise the system's effectiveness is removed from the general waste stream.

Mixed waste stored in the reservoir is loaded by a wheeled loader into a waste bag opener and the waste treatment line, and it is transported to 4 stations in the pre-sorting chamber. Waste transported by a conveyor belt is sorted manually by removing the following types of waste from the stream: obstructing waste (not removed in the waste reservoir), large pieces of plastic film, cardboard and metal. Glass, scrap metal, rubble and rocks are also removed in the pre-sorting chamber. Sorted waste is transported via disposal chutes to two containers. Different types of waste sorted in the pre-sorting chamber are transported to dedicated treatment stations in the plant. Waste with high calorific value is loaded into a preliminary shredder (without a sieve) and a biodrying system. Recyclables (metal, glass) are transported to storage compartments.

Pre-sorted waste is separated mechanically in a drum sieve into differently sized fractions. Waste is separated into two size fractions: non-sifted waste $(0-150 \mathrm{~mm})$ which is transported by a system of conveyor belts directly to biodrying chambers, and sifted waste $(>150 \mathrm{~mm})$ which is transported by a system of conveyor belts to the preliminary shredding station where it is ground to produce a fraction suitable for biodrying $(<150 \mathrm{~mm})$. Shredded waste with optimal processing size is transported to the biodrying system. A rotating drum sieve is the main device for the mechanical sorting of mixed municipal waste. Steel chutes for transporting sorted fractions to conveyer belts are located under the drum sieve [5].

\section{Innovative waste drying in bioreactors}

The Municipal Waste Treatment Plant in Olsztyn (ZUOK) has been commissioned for use in 2015. An innovative solution for drying waste without the involvement of external energy sources has been implemented in the plant. The biological waste treatment system in the Olsztyn plant has a processing capacity of $125,000 \mathrm{Mg}$ /year. Waste is transported to the plant from 37 municipalities in the Region of Warmia and Mazury. Untreated waste has an estimated moisture content of $45 \%$. Waste is dried in 14 bioreactors [1,2].

Every bioreactor measures $33 \mathrm{~m}$ in length, $7 \mathrm{~m}$ in width, and $5.5 \mathrm{~m}$ in height.

Waste stored in the mixed waste collection point (PPO) is transported to a bioreactor by a system of conveyor belts and an automatic loading system which ensures that the accumulated waste is evenly distributed without densely compacted zones that prevent air flow. Every bioreactor can accommodate $160-300 \mathrm{Mg}$ of waste, depending on its specific weight and loading conditions [2]. Biological drying chambers are equipped with aeration floors, tunnel fans and temperature sensors. The biological drying process lasts 7 to 14 days [1]. Waste is dried to a moisture content of $10-20 \%$. 


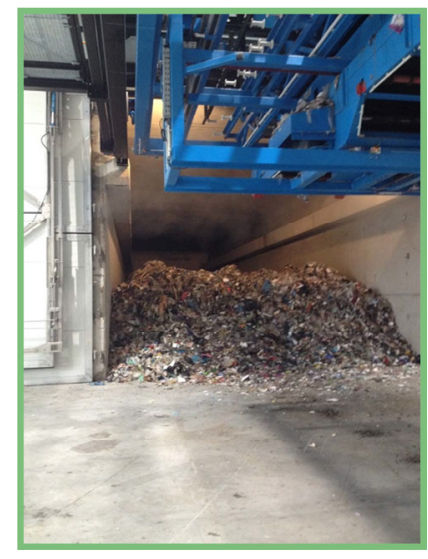

Fig. 9. Interior of a biological drying chamber.

The waste drying process in the bioreactor proceeds in the following stages:

- waste stored in the mixed waste collection point (PPO) is transported to bioreactors,

- the bioreactor gate is closed when the bioreactor is completely filled with waste, and the biological drying process is initiated,

- in the first stage of the process, the temperature inside the bioreactor is brought to an optimal level $\left(60-80^{\circ} \mathrm{C}\right)$ to generate sufficient amounts of heat for evaporating moisture from waste. The optimal temperature is achieved without the involvement of external energy sources through a series of biological processes inside the waste bed [3].

- the biological drying process begins after 1-3 days of heat generation. Heat generated in the first stage of the process (in a different reactor) and heat generated in a given reactor is used to evaporate moisture from waste,

- during biological drying, temperature is maintained at around $50-70^{\circ} \mathrm{C}$ for $4-5$ days, after which it decreases to around $30-40^{\circ} \mathrm{C}$. The decrease in temperature indicates that the energy-generating potential of waste has been depleted and that the biological drying process is complete. The biological drying process with temperature and moisture content curves is presented in Figure 10.

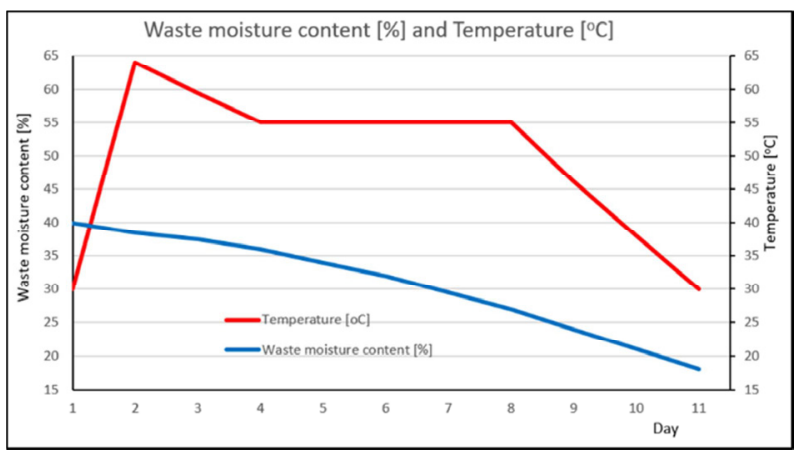

Fig. 10. Parameters of the biological drying process.

Biological drying decreases the moisture content of waste to $10-20 \%$. The weight of decomposed and dehydrated waste is reduced by around 30\%. The decomposition of waste organic matter generates heat. In heat exchangers, air is heated by exhaust air, and it is used for waste drying in bioreactors. After 7-14 days, dried waste is unloaded from bioreactors and transported to the mechanical waste treatment station (SMP) [1]. 


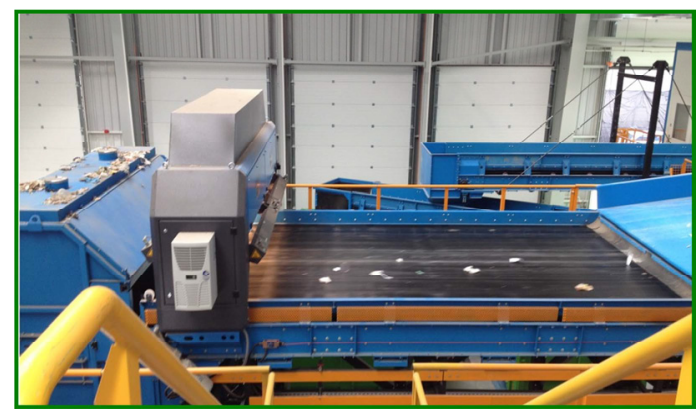

Fig. 11. Mechanical waste treatment station.

The biological drying system is composed of the following elements:

1. Biological drying chamber

2. Dried waste

3. Aeration floor

4. Drainage system (for evacuating process water)

5. Chamber gate

6. Pressure chamber

7. Main fresh air duct
8. Main exhaust air duct

9. Recirculation module

10. Heat exchanger (2 units)

11. Fan

12. Temperature sensor

13. Ceiling

14. Insulation

15. Inspection hatch

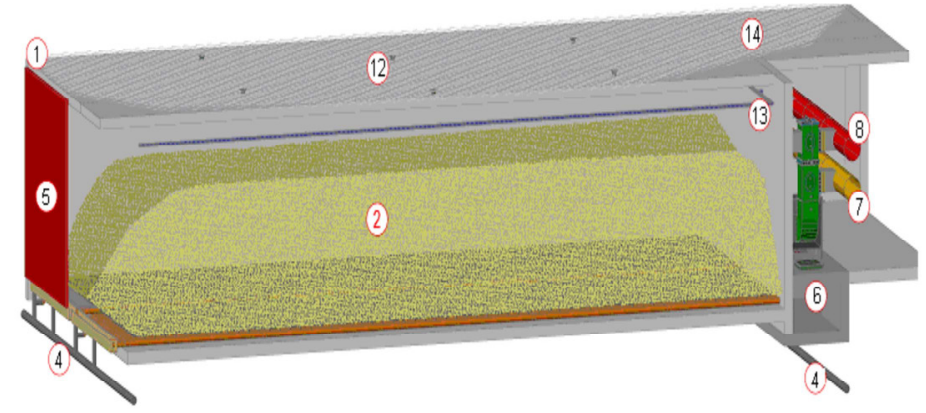

Fig. 12. Cross-section of a biological drying chamber.

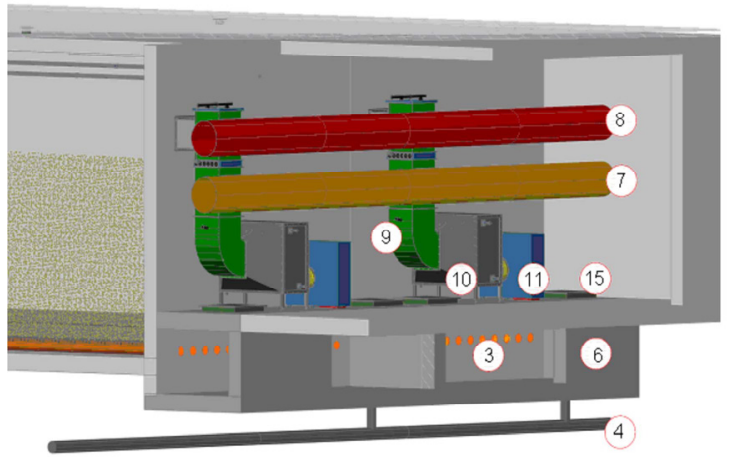

Fig. 13. Rear view of a biological drying chamber. 


\section{Conclusions}

The waste treatment line in the Municipal Waste Treatment Plant in Olsztyn has been in operation for two years, and it effectively processes municipal waste. In the first stage of the process, waste sorted at household level is separated from the waste stream, and in the following stage, mixed waste is separated in ZUOK into size fractions for bio drying. The process of bio drying of waste is an innovative and justified process due to energy efficiency. Treated waste is used in the production of alternative fuel.

\section{References}

1. Waste Act of 14 December 2012

2. Announcement of the Sejm Marshal of the Republic of Poland of 9 June 2017 on the publication of the consolidated text of the Act on the maintenance of cleanliness and order in municipalities

3. http://twojkurierolsztynski.pl/2937,2015,10,22,zaklad-unieszkodliwiania-odpadowkomunalnych-w-olsztynie-oficjalnie-otwarty (access 10.05.2017)

4. http://www.razemcieplej.pl/data/pages/47/Pozyskiwanie\%20energii\%20cieplnej\%20z\% 20odpad\%C3\%B3w.pdf (accessed on 10 May 2017)

5. Source materials from the Municipal Waste Treatment Plant in Olsztyn 2017 